\title{
CONTROL OF OVULATION AFTER PROSTAGLANDIN TREATMENT BY MEANS OF ULTRASONOGRAPHY AND EFFECT OF THE TIME OF OVULATION ON CONCEPTION RATE IN DAIRY COWS
}

\author{
Attila RÉPÁSI ${ }^{1}$, Zoltán SZELÉNYI ${ }^{2}$, Jenő REICZIGEL ${ }^{3}$, Árpád Csaba BAJCSY ${ }^{2}$, \\ András HORVÁTH ${ }^{2}$ and Ottó SZENCI ${ }^{2 *}$ \\ ${ }^{1}$ Kenézlő Dózsa Agricultural Ltd., Kenézlő, Hungary; ${ }^{2}$ Clinic for Large Animals, \\ Faculty of Veterinary Science, Szent István University, Dóra major, H-2225 Üllő, \\ Hungary; ${ }^{3}$ Department of Biomathematics and Informatics, Faculty of Veterinary \\ Science, Szent István University, Budapest, Hungary
}

(Received 29 June 2012; accepted 11 December 2012)

Primiparous and multiparous lactating crossbred dairy cows (after Day 40 postpartum) with a mature corpus luteum (CL) (diameter of $\geq 17 \mathrm{~mm}$ determined by ultrasonography) and having a follicle with a diameter of $\geq 10 \mathrm{~mm}$ were treated with natural prostaglandin $\mathrm{F}_{2 \alpha}(\mathrm{n}=80)$. Those from the cows that showed oestrus within 5 days after treatment were inseminated (Group 1: $\mathrm{n}=39$ ). Other group of cows showing oestrus without treatment (Group 2: $\mathrm{n}=41$ ) were inseminated and served as controls. The ovaries of each cow were scanned by transrectal ultrasonography from the day of detected oestrus (Day $-1_{\mathrm{p} . \mathrm{m} \text {. }}$ ) until ovulation, to measure the changes in the areas of the CL and the largest follicle and to determine the occurrence of ovulation. Although no significant differences were found between the treated and untreated cows in terms of a reduction in the area of the corpora lutea and of an increase in the area of the dominant follicles, the mean area of these follicles in Group 2 was somewhat greater than in Group 1. The highest conception rate was achieved if AI was performed at the same day as ovulation occurred in both groups (conception rate in treated group was: $62.5 \%$, in untreated group: $66.6 \%$, respectively) between Day $0_{\text {a.m. }}$ to Day $0_{\text {p.m. }}$. In Group 1 , $54.5 \%$ conception rate has been achieved if ovulation occurred between Day $0_{\text {p.m. }}$. to Day $1_{\text {p.m. }}$, or $50 \%$ between Day $1_{\text {p.m. }}$ to Day $2_{\text {p.m. }}$ after AI, and $53.3 \%$ and $44.4 \%$ in Group 2, respectively. The conception rate for cows that ovulated before AI in Group 2 was $25 \%$. No ovulation occurred in 7 cows until Day $2_{\text {p.m. }}$ after AI and none of them became pregnant. The overall conception rate was approximately $50 \%$ in both groups, but when the cows had ovulated too early or too late relative to the time of AI, the conception rate was significantly lower, thus determination of the optimal time for AI is of great practical importance in dairy herds.

Key words: Prostaglandin $F_{2 \alpha}$, ultrasonography, time of ovulation, conception rate, dairy cow

*Corresponding author; E-mail: Szenci.Otto@aotk.szie.hu; Phone: 0036 (29) 521-301; Fax: 0036 (29) 521-303 
Fertility in lactating dairy cows decreased from $66 \%$ in 1951 to about $50 \%$ until 1975, and has continued to decrease ever since to about $33.1 \%$ in Spain (López-Gatius, 2003), 33.4\% in Israel (Galon, 2008), 37\% in Canada (Bouchard and Du Tremblay, 2008) and 41\% in Japan (Nakao, 2008). Several factors contribute to the reduction of fertility in lactating dairy cows, such as negative energy balance (Butler and Smith, 1989; Sklan et al., 1994), toxic concentrations of urea nitrogen (Ferguson et al., 1993), heat stress (Badinga et al., 1985; Lucy et al., 1986), and some vitamin and mineral deficiencies (Arechiga et al., 1994). The physiological effects of these factors have been difficult to assess because physiological and management factors including competence and skills of the inseminator, proper handling of frozen semen, correct placement of semen in the uterus, and fertility of both the semen and the cow (Archbald et al., 1993) may alter the accuracy and reliability of oestrus detection as well as the conception rate after artificial insemination (AI) (Pursley et al., 1996).

In dairy cows, ovulation generally occurs 10 to $12 \mathrm{~h}$ after the disappearance of oestrous signs or 18 to $26 \mathrm{~h}$ after the LH peak that stimulates ovulation (Arthur et al., 1996). The lifespan of the ovum is relatively short, varying between a few and $10 \mathrm{~h}$ with a maximum of 20 to $24 \mathrm{~h}$ after ovulation, while sperm cells have a longer lifespan (18 to $24 \mathrm{~h}$ with a maximum of 30 to $48 \mathrm{~h}$ ) and they have to undergo capacitation before being able to fertilise the ovum (Saacke, 2008). After this period, fertility declines progressively. The longevity of germ cells depends on a variety of factors, therefore it is impossible to give precise figures for their lifespans.

Trimberger and Davis (1943) reported the association between conception rate and the time of AI. If AI was performed earlier than $12 \mathrm{~h}$ before the end of oestrus, the conception rate was $44 \%$, if at more than $6 \mathrm{~h}$ before the end of oestrus, it was $82.5 \%$, while if at $6 \mathrm{~h}$ after the end of the oestrus, it was $62.5 \%$. Conception rate decreased if AI was performed later relative to the time of oestrus. After $48 \mathrm{~h}$, the conception rate was $0 \%$. In a study with 111 dairy cows, aimed at determining conception rate at Day 28 as related to the time of ovulation, conception rate was $30 \%$ if ovulation occurred before $\mathrm{AI}$, and it was $52 \%$ and $50 \%$ if ovulation occurred within 24 or $48 \mathrm{~h}$ after AI, respectively (Van Eerdenburg et al., 2002). However, if ovulation occurred later than 48 hours after AI, conception rate was only $15 \%$. The authors concluded that the optimum time for AI was when ovulation took place within 24 hours after AI.

Prostaglandin treatment may influence the interval from the onset of oestrus to ovulation and the fertility rates during the period between AI and ovulation. Colazo et al. (2002) reported that after a 500- $\mu$ g intramuscular cloprostenol treatment in two experiments (using 6 and 9 beef heifers) the mean interval from oestrus to ovulation was $28 \mathrm{~h}$ and $45 \mathrm{~h}$, respectively. However, the fertility rate was not examined. Similarly, the length of the interval from the day of treatment to the day of post-treatment ovulation was different, depending on the appear- 
ances of follicular waves (Wave 1: $4.2 \pm 0.1$ days; Wave 2: $6.3 \pm 0.3$ days) at treatment (Kastelic and Ginther, 1991).

The aim of the present study was to detect the time of ovulation by means of ultrasonography in prostaglandin-treated and untreated dairy cows from the day of detected oestrus. Furthermore, conception rate in relation to the time of ovulation was analysed.

\section{Materials and methods}

Animals

A field study was conducted in two dairy farms of Kenézlő Agricultural Ltd., Kenézlö, Hungary, where the average milk production was 6744 and $5839 \mathrm{~kg}$ / cow/year, respectively, between December and May of the investigated year. During the examined period, the mean conception rate for the first AI was $34.8 \pm$ $9.0 \%$ and the mean conception rate for all AIs was $37.6 \pm 8.2 \%$. At both farms, cows were housed in a free stall operation and monitored for heat twice daily (a.m. and p.m.). Cows showing standing heat were inseminated by the herd managers once, according to the farm technology, in the morning (between 6:00 and 7:00 a.m.). The semen used for AI was chosen as part of the routine management of the herds.

\section{Treatments and examinations}

Primiparous and multiparous crossbred cows (Holstein-Friesian and Hungarian Simmental) after postpartum day 40 with a physiological uterine size (the entire uterus was located within the pelvic inlet; Répási et al., 2003), and with a body condition score of 3.0 to 3.5 (using a scale ranging from 0 to 5; Wildman et al., 1982) were used. Cows $(\mathrm{n}=80)$ that had a mature corpus luteum (CL; longitudinal diameter $\geq 17 \mathrm{~mm}$ ) without a cavity (Colazo et al., 2002; Répási et al., 2003 ) and a large follicle (longitudinal diameter $\geq 10 \mathrm{~mm}$ ) determined by ultrasonography (Répási et al., 2003) using a B-mode scanner equipped with a 7.5 MHz linear-array transducer (Type 450, Pie Medical, Maastricht, The Netherlands) were treated with $\mathrm{PGF}_{2 \alpha}$ (Enzaprost ${ }^{\circledR}$, Sanofi Sante Nutrition Animale, Libourne, France), and were artificially inseminated if they showed oestrus within 5 days after treatment (Group 1: $\mathrm{n}=39$ ). Other cows that were not treated with prostaglandin but showed oestrus, were inseminated after oestrus detection and served as controls (Group 2: $\mathrm{n}=41$ ). All cows showing standing oestrus were detected during the afternoons (Day $-1_{\text {p.m. }}$ ) and were inseminated between 6:00 and 7:00 a.m. during the consecutive mornings (Day $0_{\text {a.m. }}$ ). The day of AI was considered as Day $0_{\text {a.m. }}$. According to the farm technology, all inseminated cows were examined for pregnancy by rectal palpation between Days 45 and 75 after AI. 
The evaluation of the positions and diameters of the CL and the largest follicles was started on the day of detected oestrus (Day $-1_{\text {p.m. }}$, between 4:00 and 6:00 p.m.) by means of ultrasonography and was then continued daily (p.m.) until ovulation. When ovulation occurred, ultrasonographic examinations were discontinued and the area of the CL was not determined. After removing the faeces, the transducer was inserted into the rectum, and each ovary was scanned several times in lateromedial and dorsoventral planes, to determine both the position and diameters (height, width) of the CL and the largest follicle, as described previously (Répási et al., 2003; Répási et al., 2005).

Since the time of ovulation was compared to the date of AI and the conception rate, animals were further divided into the following five subgroups: Subgroup 1: ovulations preceding AI, Subgroup 2: ovulations occurring between Day $0_{\text {a.m. }}$ and Day $0_{\text {p.m. }}$, Subgroup 3: ovulations occurring between Day $0_{\text {p.m. }}$ and Day $1_{\text {p.m. }}$ after AI, Subgroup 4: ovulations occurring between Day $1_{\text {p.m. }}$ and Day $2_{\text {p.m. }}$ after AI, Subgroup 5: ovulations not occurring until Day $2_{\text {p.m. }}$.

\section{Statistical analysis}

The areas of the CL (the area of the two-dimensional ultrasonographic image of the CL) and the areas of the largest follicles (the area of the twodimensional ultrasonographic image of the largest follicle) were calculated according to the following equation:

$$
\text { area }=0.5 \mathrm{a} \times 0.5 \mathrm{~b} \times \pi
$$

where $\mathrm{a}=$ height, $\mathrm{b}=$ width (Kastelic et al., 1990).

Conception rate was calculated by dividing the number of cows diagnosed as pregnant by the number of cows inseminated after a detected oestrus.

Changes in the measured parameters were analysed by a repeatedmeasures ANOVA procedure, where the statistical model included the time of sampling and the groups as dependent variables. Differences in conception rates were evaluated by Fisher's exact test. Statistical calculations were made by SPLUS 2000 (Armitage and Berry, 1994).

\section{Results}

Mean values of the area of the CL in Groups 1 and 2 from the day of detected oestrus until ovulation are presented in Table 1. Distribution of the undetected CL was similar in each group during the experiment; however, if ovulation occurred, the presence of a CL was not examined. The mean area of the CL in cows that ovulated during the experiment changed from $132.7 \mathrm{~mm}^{2}$ to $102.5 \mathrm{~mm}^{2}$ in Group 1, from $160.5 \mathrm{~mm}^{2}$ to $111.8 \mathrm{~mm}^{2}$ in Group 2, and from $199.7 \mathrm{~mm}^{2}$ to $145.1 \mathrm{~mm}^{2}$ in the non-ovulated cows, respectively. There were no significant differences among the groups. 
Table 1

Mean area $\left(\mathrm{mm}^{2}\right)$ of the corpus luteum (CL) in ovulated (Groups 1 and 2) and non-ovulated dairy cows $( \pm \mathrm{SD})$

\begin{tabular}{|c|c|c|c|c|}
\hline Parameter & $\begin{array}{c}\mathrm{D}-1_{\mathrm{p} . \mathrm{m} .} \\
\text { (detection of } \\
\text { oestrus) }\end{array}$ & $\begin{array}{l}\mathrm{D} 0_{\text {a.m. }} \\
\text { (AI) }\end{array}$ & $\begin{array}{c}\mathrm{D} 0_{\text {p.m. }} \\
\text { after A.I. }\end{array}$ & $\begin{array}{c}\mathrm{D} 1_{\mathrm{p} . \mathrm{m} .} \\
\text { after A.I. }\end{array}$ \\
\hline \multicolumn{5}{|l|}{ Group 1} \\
\hline Cow (n) & 33 & 13 & 2 & \\
\hline CL (n) & $31+4^{*}$ & $13+1^{*}$ & 2 & \\
\hline Area $\left(\mathrm{mm}^{2}\right) \pm \mathrm{SD}$ & $132.7 \pm 56.3$ & $121.9 \pm 49.6$ & 102.5 & \\
\hline Min. area $\left(\mathrm{mm}^{2}\right)$ & 56.5 & 62.8 & 99.0 & \\
\hline $\operatorname{Max} . \operatorname{area}\left(\mathrm{mm}^{2}\right)$ & 252.9 & 227.0 & 106.0 & \\
\hline $\operatorname{NDCL}(\mathrm{n})$ & 2 & 4 & 5 & \\
\hline \multicolumn{5}{|l|}{ Group 2} \\
\hline Cow (n) & 40 & 19 & 3 & \\
\hline CL (n) & $33+1^{*}$ & $19+1^{*}$ & 3 & \\
\hline Area $\left(\mathrm{mm}^{2}\right) \pm \mathrm{SD}$ & $160.5 \pm 67.1$ & $137.9 \pm 36.7$ & 111.8 & \\
\hline Min. area $\left(\mathrm{mm}^{2}\right)$ & 70.7 & 78.5 & 110.0 & \\
\hline Max. area $\left(\mathrm{mm}^{2}\right)$ & 298.5 & 208.9 & 113.1 & \\
\hline NDCL (n) & 3 & 5 & 6 & \\
\hline \multicolumn{5}{|l|}{ No ovulation ${ }^{* *}$} \\
\hline Cow (n) & 7 & 6 & 4 & 2 \\
\hline CL (n) & 7 & 6 & 4 & 2 \\
\hline Area $\left(\mathrm{mm}^{2}\right) \pm \mathrm{SD}$ & $199.7 \pm 76.0$ & $166.1 \pm 41.0$ & 145.1 & 188.5 \\
\hline Min. area $\left(\mathrm{mm}^{2}\right)$ & 78.5 & 138.2 & 71.5 & 117.8 \\
\hline Max. area $\left(\mathrm{mm}^{2}\right)$ & 293.7 & 245 & 301.6 & 259.2 \\
\hline NDCL (n) & - & 1 & 3 & 5 \\
\hline
\end{tabular}

*Number of cows with double corpora lutea; ${ }^{* *}$ Six cows in Group 1 and one cow in Group 2 did not ovulate during the experiment; SD: standard deviation; Min.: minimum; Max.: maximum; NDCL: no detectable corpus luteum

The changes in the mean areas of the largest follicles are shown in Table 2. They were somewhat greater in untreated cows and in those that did not ovulate, but the difference was not statistically significant. Ovulation did not occur in 6 cows that had been treated with prostaglandin previously and in one cow of the control group.

The time of ovulation as related to AI was estimated by ultrasonography and the dataset was also evaluated according to the day of ovulation and compared with the fertility results (Table 3). The ovulation rate in Group 1 was $41 \%$ if ovulation occurred between Day $0_{\text {a.m. }}$ and Day $0_{\text {p.m. }}, 28.2 \%$ if ovulation occurred between Day $0_{\text {p.m. }}$ and Day $1_{\text {p.m. }}$ after AI, and $15.4 \%$ if ovulation occurred between Day $1_{\text {p.m. }}$ and Day $2_{\text {p.m. }}$ after AI. In Group 1 , none of the cows ovulated before AI. In Group 2 this rate was $9.8 \%$ for cows that had ovulated before AI 
and it was $29.3 \%, 36.6 \%$ and $22 \%$ if ovulation occurred between Day $0_{\text {a.m. }}$ and Day $2_{\text {p.m. }}$, respectively. A few cows (Group 1: $\mathrm{n}=6,15.4 \%$ and Group 2: $\mathrm{n}=1$, $2.4 \%$ ) did not ovulate until Day $2_{\text {p.m. }}$.

Table 2

Mean area $\left(\mathrm{mm}^{2}\right)$ of the largest follicle in ovulated (Groups 1 and 2) and non-ovulated dairy cows $( \pm \mathrm{SD})$

\begin{tabular}{|c|c|c|c|c|}
\hline Parameter & $\begin{array}{c}\mathrm{D}-1_{\text {p.m. }} \\
\text { (detection of } \\
\text { oestrus) }\end{array}$ & $\begin{array}{l}\mathrm{D} 0_{\text {a.m. }} \\
\text { (AI) }\end{array}$ & $\begin{array}{l}\mathrm{D} 0_{\mathrm{p} . \mathrm{m} .} \\
\text { after A.I. }\end{array}$ & $\begin{array}{c}\mathrm{D} 1_{\mathrm{p} . \mathrm{m} .} \\
\text { after A.I. }\end{array}$ \\
\hline \multicolumn{5}{|l|}{ Group $1^{*}$} \\
\hline Cow (n) & 33 & 17 & 6 & \\
\hline Follicle (n) & 34 & 17 & 6 & \\
\hline Area $\left(\mathrm{mm}^{2}\right) \pm \mathrm{SD}$ & $214.5 \pm 66.7$ & $228.9 \pm 73.1$ & $239.9 \pm 88.1$ & \\
\hline Min. area $\left(\mathrm{mm}^{2}\right)$ & 88.0 & 141.4 & 149.2 & \\
\hline Max. area $\left(\mathrm{mm}^{2}\right)$ & 373.1 & 392.7 & 379.3 & \\
\hline \multicolumn{5}{|l|}{ Group $2^{* *}$} \\
\hline Cow (n) & 36 & 24 & 9 & \\
\hline Follicle (n) & 37 & 25 & 9 & \\
\hline Area $\left(\mathrm{mm}^{2}\right) \pm \mathrm{SD}$ & $227.1 \pm 55.1$ & $254.8 \pm 62.8$ & $276.2 \pm 80.1$ & \\
\hline Min. area $\left(\mathrm{mm}^{2}\right)$ & 106.8 & 160.2 & 200.3 & \\
\hline Max. area $\left(\mathrm{mm}^{2}\right)$ & 380.1 & 478.3 & 433.5 & \\
\hline \multicolumn{5}{|l|}{ No ovulation } \\
\hline Cow (n) & 7 & 7 & 7 & 7 \\
\hline Follicle (n) & 7 & 7 & 7 & 7 \\
\hline Area $\left(\mathrm{mm}^{2}\right) \pm \mathrm{SD}$ & $264.9 \pm 166.6$ & $248.2 \pm 176.7$ & $258.2 \pm 169.5$ & $282.9 \pm 164.8$ \\
\hline Min. area $\left(\mathrm{mm}^{2}\right)$ & 129.3 & 128.2 & 129.6 & 150.8 \\
\hline Max. area $\left(\mathrm{mm}^{2}\right)$ & 628.3 & 628.3 & 628.3 & 628.3 \\
\hline
\end{tabular}

* Six cows did not ovulate during the experiment and 1 cow had two large follicles (both ovulated on Day 0 ); ${ }^{* *}$ Four cows ovulated before AI, 1 cow did not ovulate during the experiment and 1 cow had two follicles (both ovulated on Day 1); SD: standard deviation; Min.: minimum; Max.: maximum

The mean areas of the ovulatory follicles on the day before ovulation were somewhat smaller in Group 1 than in Group 2; however, the differences were not significant (Table 3). Conception rate in Group 1 was $62.5 \%$ if ovulation occurred between Day $0_{\text {a.m. }}$ and Day $0_{\text {p.m. }}, 54.5 \%$ if ovulation occurred until Day $0_{\text {p.m. }}$ and Day $1_{\text {p.m. }}$ after AI, and $50 \%$ if ovulation occurred between Day $1_{\mathrm{p} . \mathrm{m} \text {. }}$ and Day $2_{\text {p.m. }}$ after AI, respectively. In Group 2, conception rate was $25 \%$ for cows that had ovulated before AI and it was $66.6 \%, 53.3 \%$, and $44.4 \%$ with ovulations occurring between Day $0_{\text {a.m. }}$ and Day $2_{\text {p.m. }}$, respectively. Pregnancy could not be detected if cows did not ovulate until Day $2_{\text {p.m. }}$ after AI.

The mean area of the ovulatory follicles was larger if ovulation occurred later after AI in both groups; however, the differences were not statistically significant (Table 3). 
Table 3

The time of ovulation and the mean area (just prior to ovulation) of the ovulated follicles in relation to the dates of $\mathrm{AI}$ and conception rates

\begin{tabular}{|c|c|c|c|c|c|}
\hline Parameter & $\begin{array}{l}\text { Ovulation } \\
\text { before AI } \\
\text { (n) }\end{array}$ & $\begin{array}{l}\text { Ovulation } \\
\text { between } \\
\mathrm{D} 0_{\text {a.m. }} \text { and } \\
\text { D0 } \\
\text { (n) }\end{array}$ & $\begin{array}{l}\text { Ovulation } \\
\text { between } \\
\mathrm{D} 0_{\text {p.m. }} \text { and } \\
\text { D1 } \\
\text { (n).m. }\end{array}$ & $\begin{array}{l}\text { Ovulation } \\
\text { between } \\
\mathrm{D} 1_{\text {p.m. }} \text { and } \\
\mathrm{D} 2_{\text {p.m. }} \\
\text { (n) }\end{array}$ & $\begin{array}{l}\text { No ovulation } \\
\text { until D } 2_{\text {p.m. }} \\
\text { (n) }\end{array}$ \\
\hline \multicolumn{6}{|l|}{ Group 1} \\
\hline Cow (n) & 0 & $16^{*}$ & 11 & 6 & 6 \\
\hline $\begin{array}{l}\text { Area of the largest } \\
\text { follicle on the day } \\
\text { before ovulation } \\
\left(\mathrm{mm}^{2} \pm \mathrm{SD}\right)^{* *}\end{array}$ & & $212.3 \pm 66.1$ & $229.2 \pm 63.1$ & $239.9 \pm 88.1$ & $280.3 \pm 180.4$ \\
\hline Conception rate, $\mathrm{n}(\%)$ & $0(0)$ & $10(62.5)$ & $6(54.5)$ & $3(50)$ & $0(0)$ \\
\hline \multicolumn{6}{|l|}{ Group 2} \\
\hline Cow (n) & 4 & 12 & $15^{*}$ & 9 & 1 \\
\hline $\begin{array}{l}\text { Area of the largest } \\
\text { follicle on the day } \\
\text { before ovulation } \\
\left(\mathrm{mm}^{2} \pm \mathrm{SD}\right)^{* *}\end{array}$ & ovulated & $227.3 \pm 51.1$ & $239.0 \pm 48.6$ & $276.2 \pm 80.1$ & 298.5 \\
\hline Conception rate, $\mathrm{n}(\%)$ & $1(25)$ & $8(66.6)$ & $8(53.3)$ & $4(44.4)$ & $0(0)$ \\
\hline
\end{tabular}

* One cow had two follicles; ${ }^{* *}$ There were no significant differences in the areas of the largest follicles within the groups and between the groups. ANOVA: P > 0.1; SD: standard deviation

\section{Discussion}

The mean area of the CL gradually decreased after the detection of oestrus in each group. At the same time, their mean area was consistently higher in cows that did not show ovulation $(\mathrm{n}=7)$. However, these differences were not statistically significant either among the groups or within them.

The changes in the area of the CL both in the non-treated and the prostaglandin-treated cows were comparable to those described in previous reports (Kastelic et al., 1990; Assey et al., 1993; Son et al., 1995).

There were large variations in the area of the CL in the prostaglandintreated (Group 1) and untreated cows (Group 2) during the periods examined (Table 1). In harmony with our recent findings showing large variations in the area of the CL in both groups, Assey et al. (1993) reported pronounced individual variations in plasma P4 concentrations and CL sizes in heifers and cows due to the cloprostenol-induced regression of the CL. In contrast, the luteal tissue area and CL size were reported to be highly correlated with plasma P4 concentra- 
tion in heifers and cows during natural luteal regression (Sprecher et al., 1989; Kastelic et al., 1990) and during induced luteolysis both in heifers (Assey et al., 1993) and cows (Répási et al., 2005), while no similar correlation was found in our previous study (Répási et al., 2003), in conformity with the findings of Assey et al. (1993).

At the same time, no attempt has been made to determine the luteal function in cows without a detected CL (Smith et al., 1998). In a more recent study, Roelofs et al. (2006) concluded that monitoring P4 alone is not sufficient to predict ovulation due to the large individual variation in the timing of P4 concentration decrease relative to ovulation. The importance of this is emphasised by the fact that 5 to $30 \%$ of inseminations are carried out when the animal is not in oestrus (Senger et al., 1988); therefore, it would be very important for the field practice to have an accurate diagnostic tool enabling the accurate detection of cows that are not in oestrus.

According to Van Eerdenburg et al. (2002), in non-treated dairy cows the mean area of the largest follicle was $204 \mathrm{~mm}^{2}, 205 \mathrm{~mm}^{2}$ and $215 \mathrm{~mm}^{2}$ on Days 0 , 1 and 2, respectively. Similar results were found in our study as shown in Table 2. In agreement with the findings of Van Eerdenburg et al. (2002), the mean area of the ovulatory follicle on the day before ovulation was somewhat, but not significantly, smaller if ovulation occurred later in relation to AI as detailed in Table 3.

The time of ovulation in relation to AI was estimated by ultrasonography and the dataset was compared with the fertility results. We found the highest rate of ovulating cows between Day $0_{\text {a.m. }}$ and Day $0_{\text {p.m. }}$ in Group $1(41 \%)$ and between Day $0_{\text {p.m. }}$ and Day $1_{\text {p.m. }}(36.6 \%)$ in Group 2.

In the study of Van Eerdenburg et al. (2002), the highest ovulation rate was observed between 0 and $24 \mathrm{~h}$ after insemination (56.2\%). According to Walker et al. (1996), the mean ovulation time relative to the first mount was $27.6 \pm 5.4 \mathrm{~h}$ without any difference between spontaneous and $\mathrm{PGF}_{2 \alpha}$-induced oestrus. When ovulation occurred before AI, the conception rate was 30\% (Van Eerdenburg et al., 2002), while it was $25 \%$ in Group 2 in our study. The highest conception rate was detected if ovulation occurred on the day of AI in each group (62.5\% in Group 1 vs. $66.6 \%$ in Group 2). According to Van Eerdenburg et al. (2002), conception rate was $52 \%$ if the cow ovulated within $24 \mathrm{~h}$ after AI. Arthur et al. (1996) indicated a 13- to 18-h window in which AI can be performed in relation to ovulation. In our study, $54.5 \%$ and $50 \%$ conception rates were achieved in Group 1 while $53.3 \%$ and $44.4 \%$ in Group 2 if ovulation occurred between Day $0_{\text {p.m. }}$ and Day $1_{\text {p.m. }}$ or between Day $1_{\text {p.m. }}$ and Day $2_{\text {p.m. }}$ after AI, respectively.

Van Eerdenburg et al. (2002) reported that $15 \%$ of the cows became pregnant if they had ovulated more than 48 hours after AI. At the same time, in our study none of the cows that did not ovulate until Day $2_{\text {p.m. }}$ after AI became pregnant.

The overall conception rate of cows selected for this study was about $50 \%$ in both groups, but when the cows had ovulated too early or too late in relation to 
the time of AI, the conception rate was significantly lower. It is very important to emphasise that some cows (3 to 6\%) treated with a second GnRH as part of the Ovsynch protocol fail to ovulate (Gumen et al., 2003); therefore, determination of the optimal time of AI is of great practical importance in dairy operations. If ovulation does not occur within two days after AI, a second AI may be performed. However, further studies are needed to evaluate the benefits of the second AI in cases of delayed ovulation or a GnRH (or agonist) treatment at the time of insemination (Stevenson et al., 1990) to improve fertility.

\section{References}

Archbald, L. F., Risco, C., Chavette, P., Constant, S., Tran, T., Klapstein, E. and Elliot, J. (1993): Estrus and pregnancy rate of dairy cows given one or two doses of prostaglandin F2 alpha 8 or 24 hours apart. Theriogenology 40, 873-884.

Arechiga, C. F., Ortiz, O. and Hansen, P. J. (1994): Effect of prepartum injection of vitamin E and selenium on postpartum reproductive function of dairy cattle. Theriogenology 41, 1251-1260.

Armitage, P. and Berry, G. (1994): Statistical Methods in Medical Research. Third edition. Blackwell Science, Oxford, England.

Arthur, G., Noakes, D., Pearson, H. and Parkinson, T. (1996): Veterinary Reproduction and Obstetrics. Seventh edition. W. B. Saunders Company Limited, London.

Assey, R. J., Purwantara, B., Greve, T., Hyttel, P. and Schmidt, M. H. (1993): Corpus luteum size and progesterone levels in cattle after cloprostenol induced luteolysis. Theriogenology 39, $1321-1330$.

Badinga, L., Collier, R. J., Thatcher, W. W. and Wilcox, C. J. (1985): Effects of climatic and management factors on conception rate of dairy cattle in subtropical environment. J. Dairy Sci. 68, 78-89.

Bouchard, E. and Du Tremblay, D. (2008): Dairy herd production and reproduction in Quebec and Canada. In: Szenci, O. and Bajcsy, Á. Cs. (eds) Factors Affecting Reproductive Performance in the Cow. Hungarian Association for Buiatrics, Budapest, Hungary. pp. 60-66.

Butler, W. R. and Smith, R. D. (1989): Interrelationships between energy balance and postpartum reproductive function in dairy cattle. J. Dairy Sci. 72, 767-783.

Colazo, M. G., Martínez, M. F., Kastelic, J. P. and Mapletoft, R. J. (2002): Effects of dose and route of administration of cloprostenol on luteolysis, estrus and ovulation in beef heifers. Anim. Reprod. Sci. 72, 47-62.

Ferguson, J. D., Galligan, D. T., Blanchard, T. and Reeves, M. (1993): Serum urea nitrogen and conception rate: the usefulness of test information. J. Dairy Sci. 76, 3742-3750.

Galon, N. (2008): Factors affecting reproductive performance in Israeli dairy herds. In: Szenci, O. and Bajcsy, Á. Cs. (eds) Factors Affecting Reproductive Performance in the Cow. Hungarian Association for Buiatrics, Budapest, Hungary. pp. 28-36.

Gumen, A., Guenther, J. N. and Wiltbank, M. C. (2003): Follicular size and response to Ovsynch versus detection of estrus in anovular and ovular lactating dairy cows. J. Dairy Sci. 86, 3184-3194.

Kastelic, J. P. and Ginther, O. J. (1991): Factors affecting the origin of the ovulatory follicle in heifers with induced luteolysis. Anim. Reprod. Sci. 26, 13-24.

Kastelic, J. P., Pierson, R. A. and Ginther, O. J. (1990): Ultrasonic morphology of corpora lutea and central luteal cavities during the estrous cycle and early pregnancy in heifers. Theriogenology 34, 487-498. 
López-Gatius, F. (2003): Is fertility declining in dairy cattle? A retrospective study in northeastern Spain. Theriogenology 60, 89-99.

Lucy, M. C., Rowlands, G. S. and Russel, A. M. (1986): The association between lameness and fertility in dairy cows. Vet. Rec. 118, 628-640.

Nakao, T. (2008): Declining fertility in dairy cows in Japan and efforts to improve the fertility. In: Szenci, O. and Bajcsy, Á. Cs. (eds) Factors Affecting Reproductive Performance in the Cow. Hungarian Association for Buiatrics, Budapest, Hungary. pp. 38-48.

Pursley, J., Michael, R., Kosorok, R. and Wiltbank, M. C. (1996): Reproductive management of lactating dairy cows using synchronization of ovulation. J. Dairy Sci. 80, 301-303.

Répási, A., Beckers, J. F., Sulon, J., Perényi, Zs., Reiczigel, J. and Szenci, O. (2003): Effect of different doses of prostaglandin on the area of corpus luteum, the largest follicle and progesterone concentration in the dairy cow. Reprod. Domest. Anim. 38, 1-6.

Répási, A., Beckers, J. F., Sulon, J., Karen, A., Reiczigel, J. and Szenci, O. (2005): Effect of the type and number of prostaglandin treatments on corpus luteum, the largest follicle and progesterone concentration in dairy cow. Reprod. Domest. Anim. 40, 1-7.

Roelofs, J. B., van Eerdenburg, F. J. C. M., Hazeleger, W., Soede, N. M. and Kemp, B. (2006): Relationship between progesterone concentrations in milk and blood and time of ovulation in dairy cattle. Anim. Reprod. Sci. 91, 337-343.

Saacke, R. G. (2008): Insemination factors related to timed AI in cattle. Theriogenology 70, 479-484.

Senger, P. L., Becker, W. C., Davidge, S. T., Hillers, J. K. and Reveer, J. J. (1988): Influence of cornual insemination on conception in dairy cattle. J. Anim. Sci. 66, 1010-1016.

Sklan, D., Kaim, M., Moallem, U. and Folman, Y. (1994): Effect of dietary calcium soaps on milk yield, body weight, reproductive hormones, and fertility in first parity and older cows. J. Dairy Sci. 77, 1652-1656.

Smith, S. T., Ward, W. R. and Dobson, H. (1998): Use of ultrasonography to help to predict observed oestrus in dairy cows after the administration of prostaglandin $F_{2 \alpha}$. Vet. Rec. 142, 271-274.

Son, C. H., Schwarzenberger, F. and Arbeiter, K. (1995): Relationship between ultrasonographic assessment of the corpus luteum area and milk progesterone concentration during the oestrous cycle in cows. Reprod. Domest. Anim. 30, 97-100.

Sprecher, D. J., Nebel, R. L. and Whitman, S. S. (1989): The predictive value, sensitivity and specificity of palpation per rectum and transrectal ultrasonography for the determination of bovine luteal status. Theriogenology 31, 1165-1172.

Stevenson, J. S., Call, E. P., Scoby, R. K. and Phatak, A. P. (1990): Double insemination and gonadotropin-releasing hormone treatment of repeat-breeding dairy cattle. J. Dairy Sci. 73, $1766-1772$.

Trimberger, G. W. and Davis, H. P. (1943): Conception rate in dairy cattle from artificial insemination at various stages of estrus. Nebraska Agric. Exp. Stn. Res. Bull. 129, 1-14.

Van Eerdenburg, F. J. C. M., Karthaus, D., Taverne, M. A. M., Merics, I. and Szenci, O. (2002): The relationship between estrus behavioral score and time of ovulation in dairy cattle. J. Dairy Sci. 85, 1150-1156.

Walker, W. L., Nebel, R. L. and McGilliard, M. L. (1996): Time of ovulation relative to mounting activity in dairy cattle. J. Dairy Sci. 79, 1555-1561.

Wildman, E. E., Jones, G. M., Wagner, P. E. and Boman, R. L. (1982): A dairy cow body condition scoring system and its relationship to selected production characteristics. J. Dairy Sci. 65, 495-499. 